\title{
Ediciones Los hijos de la teta del ciclón (1991-1993): una comunidad literaria inconfesable
}

\author{
EMILIANO TAVERNINI CONICET, Argentina / emilianotavernini@gmail.com
}

\section{Resumen}

En el presente trabajo nos proponemos reflexionar sobre un proyecto de edición artesanal que a comienzos de la década del noventa, reunió a un grupo de poetas hijos e hijas de la militancia perseguida en los setenta. Para eso vamos a analizar lo que Silvia Schwarzböck definió como «los espantos» en las estéticas de la posdictadura, para leer de qué manera las distintas voces recurren a una «estética postparanoica». Luego nos detendremos en las políticas de memoria y en las políticas estéticas que proponen los textos para intervenir en un presente signado por la impunidad para los perpetradores. Consideramos que esta experiencia es relevante para comprender no sólo la emergencia posterior de H.I.J.O.S., sino también las producciones artísticas elaboradas por esta generación, las cuales tuvieron una etapa de aglutinación intensiva a lo largo de la década de los 2000 , en cine, artes plásticas y literatura. Además permite reivindicar diversas formas de asociación existentes entre los familiares y una comunidad más amplia, solidaria, en un contexto signado por la «teoría de la reconciliación nacional».

Palabras clave: poesía argentina / memoria / hijos de desaparecidos / editoriales alternativas
Ediciones Los hijos de la teta del ciclón (19911993): an unconfessable literary community Abstract

The present article aims to reflect on a craft publishing project that at the beginning of the nineties, brought together a group of sons and daughters poets of the militancy persecuted in the seventies. For that we are going to analyze that Silvia Schwarzböck defined as «the frights» in the post-dictatorship aesthetics, to read how the different voices resort to a "postparanoic aesthetic». Then we will stop at the memory policies and aesthetic policies proposed by the texts to intervene in a present marked by impunity for the perpetrators. We consider that this experience is relevant to understand not only the subsequent emergence of H.I.J.O.S., but also the artistic productions elaborated by this generation, which had an intensive agglutination stage throughout the 200os, in cinema, plastic arts and literature. It also allows to claim various forms of association between family members and a wider community, in solidarity, in a context marked by the «theory of national reconciliation».

Key words: Argentine poetry / memory /

childrens of disappeared / alternative publishers

Recibido: 17/6/2019. Aceptado: 9/8/2019

Para citar este artículo: Tavernini, E. (2019). Ediciones Los hijos de la teta del ciclón (1991-1993): una comunidad literaria inconfesable. El taco en la brea, 10 (junio-noviembre), 161-174. Santa Fe, Argentina: UNL. DOI: $10.14409 /$ tb.v1i10.8696 
Había tenido lugar algo que permitía por unos instantes,

a través de los malentendidos propios de las existencias singulares,

reconocer la posibilidad de una comunidad previamente establecida

al mismo tiempo que ya póstuma: nada subsistiría de ella (...)

algo así como la prueba misma de la borradura que exige la escritura.

Maurice Blanchot, La comunidad inconfesable (1982)

\section{Hallazgos, azares, coincidencias}

Hace un par de semanas recibí por correo electrónico un texto de la poeta Alejandra Szir titulado «El presente», en el que manifestaba la sorpresa que le había deparado la lectura de $E l$ sexo de las piedras (2014) de Fernando Araldi Oesterheld. En ese poemario Szir encontró una paronomasia, de gran contenido simbólico y visual, muy semejante a una que ella misma había utilizado en uno de sus últimos poemas publicados «Ni perla ni barro ni plata» (2019a):' «el miedo es un intento/ de inmovilizar la violencia/ el río se revuelve en su barro/pero si le llamaste río/revolver también es mover./ Revólver/ lago quieto porque es quieto/ lago corto porque es corto/ todo es marrón: sangre/ ojos piel caca de río». Este revolver entre los vestigios de la historia, entre los sedimentos de un río que se oculta en su oscuridad, juega con la imagen benjaminiana del ángel de la historia pero también da cuenta de la búsqueda generacional que debieron emprender los hijos de la militancia setentista en Argentina para reconstruir su propia memoria-identidad. Entre los deshechos y los restos del páramo del presente se hunde la violencia, el revólver, como estrategia de resistencia y construcción política, se hunde o aguarda. Imposible saberlo.

El yo lírico prelingüístico y prenatal que construye Araldi Oesterheld en su primer poemario, en un momento también se pregunta: «Por qué revolver en el sentido de revólver» (30). Si bien el poeta utiliza el mismo juego léxico revolver-revólver, produce otro desplazamiento de sentidos, a partir de lo que en el mismo texto se conceptualiza como memoria náusea o memoria radiactiva. El verso estaría dando cuenta de la primera opción: la memoria como saturación, melancolía, somatización, traba en el presente.

La sorpresa en Szir dio lugar a la preocupación de que se interpretara su texto como un posible plagio de la imagen utilizada en $E l$ sexo de las piedras, aunque como aclaraba había leído por primera vez el texto con posterioridad a la publicación de «Ni perla ni barro ni plata». Azarosamente, casi por la misma fecha, la poeta María Ester Alonso Morales le enviaba el último libro de Julián Axat Cuando las gasolineras sean ruinas románticas (2019a). En el poema «Inflama» se encontró con el mismo juego de palabras: «De qué miseria o fisura que la bordea/ salgo a meterme yo y revolver/ y no naturalizar — cada vez - revólver» (24). Sin dudas la coincidencia denotaba una cuestión más trascendente que la implicada en un simple plagio u homenaje. De esta manera, la utilización de la paronomasia a final de verso dota de otro ritmo al texto de Axat, instaura nuevos sentidos. La revuelta de «Inflama» ocurre entre las vidas y los materiales del presente y hace referencia a los excluidos por el modelo económico neoliberal, sistema que separa lo cercano mediante la construcción de fronteras de sólido cemento o de prejuicios sociales, en este caso mediante el distanciamiento vertical: «Tan solo del otro lado del Riachuelo/ ahí donde el factótum fabrica una torre de 60 pisos/ a medio millón de dólares con vista a la ciénaga» (24). La imagen del revólver está más indeterminada que en los poemas anteriores y podría significar tanto la amputación de la sensibilidad en una sociedad que se abisma en la negación de la otredad, como condición de 
supervivencia; así como también la reflexión de un yo lírico que desconfía de la naturalización de la violencia que transita por ese afuera.

Luego de preguntarse si estaría en presencia de un motivo ya institucionalizado en la literatura de hijos e hijas, Alejandra Szir señalaba:

en una de esas va más allá de nuestras voluntades, los revólveres revueltos son de todos. En mi caso concreto, en 2018, recibí algo que Fernando Araldi Oesterheld escribió en 2014. Sin haberlo leído, simplemente me llegó del aire y lo metí en un poema que no tiene nada que ver con el de él. Lo único en común es una pérdida, un dolor, él es lírico, yo rabiosa. La lucha armada, la guerrilla, usaba revólveres y nosotros revolvemos. Recontra volvemos con la poesía o intentos, balbuceos, autobiografías, lo que podamos. (Szir, 2019b)

Julián Axat participó del intercambio de mails con un texto titulado «El futuro (a modo de respuesta a Alejandra Szir)». Allí esbozó, en un intento por explicar el fenómeno poético detectado por Szir, el otro lado de la cara institucional de H.I.J.O.S. (Hijos e Hijas por la Identidad y la Justicia contra el Olvido y el Silencio), la comunidad inconfesable que circuló, circula y circulará tanto dentro como por fuera o en el límite de la parcelación de flujos sociales que promueve toda organización institucional:

pienso en Blanchot, y en un tipo de comunidad de desprendimiento (secreta porque se desconoce la pertenencia) que tantea palabras fantasmas que le son comunes y se repiten en los sueños de esos miembros que no saben de su pertenencia a esa comunidad latente, pero que durante la noche son los demonios que se encuentran y se toman la mano para repetir mantras de un pasado que detectaron o transfiguraron en alegorías que ahora hablan del futuro que va a suceder (...) Estaba en el ambiente, en el aire que respirábamos, y era inconsciente, pero necesitaba que alguno lo dijera y otro lo repitiera, para después descubrir que todos lo habíamos dicho. (Axat, 2019b)

En las largas entrevistas que he realizado a hijos e hijas de la militancia setentista fue un tópico común encontrar vacilaciones, dudas, afirmaciones y veloces negaciones acerca de la participación o no en la agrupación, cuando no recuerdos difusos en torno a las actividades de las que efectivamente participaron, tal como señala Maurice Blanchot a propósito de la revista Acéphale dirigida por George Bataille: quienes participaron no están seguros de haber formado parte. Sin embargo, coinciden en señalar que hubo un antes y un después de la creación de esa comunidad confesable, de sus fines y estrategias de lucha. Las razones de este fenómeno pueden ser muchas: desde la organización en red y la discusión asamblearia para la toma de decisiones, en un intento por diferenciarse de las organizaciones políticas jerárquicas de los setenta, pero también como estrategia política para contener la diversidad de identidades que circulaban por su interior; hasta la concepción del reclamo y la lucha política como hecho estético, lo cual permitía cierta permeabilidad con grupos de artistas que compartían sus demandas.

En consecuencia, encontramos comunidades volátiles, azarosas, de hijos e hijas, antes de H.I.J.O.S., ${ }^{2}$ pero también durante y después. Coinciden en la extracción de esa piedra de la locura, de ese archivo intangible compartido, que vuelve a decirse en su imposibilidad, la vivencia y las memorias de una generación atravesada por el genocidio, que dialoga con las ausencias y encuentra en la elaboración memorística y el trabajo sobre el lenguaje medios para articular 
intervenciones político-estéticas cercanas en su desemejanza. En el presente trabajo, entonces, me propongo abordar una breve experiencia de edición de poesía artesanal y autogestiva que a comienzos de los años noventa impulsó un reconocido militante del peronismo revolucionario de la ciudad de La Plata, Gonzalo Leónidas Chaves. Dentro de esta colección se publicaron los poemarios de tres hijos de la militancia setentista: Las alambradas de la luz (1991) de Gonzalo Chaves (h), ${ }^{3}$ Alas del alma (1992) e Imágenes rotas (1993) de Andrea Suarez Córica ${ }^{4}$ y Variaciones del agua soleada (1993) de Diego Larcamón. ${ }^{5}$

Si bien los textos de Suárez Córica salieron con otro sello, Autogestión ediciones, son pasibles de ser incluidos dentro de la misma intervención pública, dado que se ligan a las prácticas de Chaves como serigrafista e improvisado editor que no obstante contaba con una larga trayectoria en la prensa gráfica dentro del ámbito de la militancia. Comenzó con Octubre, una revista de la Juventud Peronista de La Plata en la que colaboraban varios de los activistas y agitadores de la resistencia peronista recluidos en el penal de Magdalena en el marco del Plan de Conmoción Interna del Estado (CONINTES) de Arturo Frondizi. Más tarde, durante la última dictadura cívico-militar, editó Confluencia sindical, órgano de prensa de la rama sindical de la organización Montoneros, mientras que más cercano en el tiempo a Los hijos de la teta del ciclón trabajaba en las publicaciones del Centro de la Memoria Popular (CEMEPO), pequeñas revistas y folletos que contribuían a la construcción de un relato contrahegemónico de los setenta, a partir de la recuperación y la visibilización del testimonio de familiares y compañeros de militantes asesinados o desaparecidos.

Con motivo de la realización de este trabajo, encontré que Chaves ya contaba con experiencia en la edición alternativa de poesía, más allá de que no lo recordara cuando realicé la entrevista. Había trabajado en el diseño gráfico y la diagramación de una editorial de poesía platense, Elepé ediciones, dirigida por Miguel Chagaray a comienzos de los setenta ${ }^{6} \mathrm{y}$ también más tarde en el diseño de Atravesando la noche. 79 sueños y testimonio acerca del genocidio (1996) de Andrea Suárez Córica.

En primer lugar es interesante señalar lo azaroso en la conformación del emprendimiento Los hijos de la teta del ciclón. En la entrevista, Chaves comentó que la idea surgió a partir de la necesidad de resolver un problema familiar. Luego del retorno al país en 1989, ${ }^{7}$ ya divorciado convivía con su hijo mayor y la relación no era fácil, este había abandonado el colegio secundario:

cuando trabajaba me iba a la mañana y volvía a la noche y siempre que volvía tenía los platos sucios, me tenía que poner a lavar. Le decía «Gonzalo, dame una mano, no seas hdp», pero no me daba bola. En un momento yo ya estaba (...) lo iba a echar a la mierda (risas), con sus cosas y todo. Pero recapacité y dije algo está pasando acá, no puede ser que mi respuesta sea así. Entonces me pareció que mi respuesta debía ser hacer algo junto con él, una tarea nuestra, porque no hacíamos cosas juntos, él tenía sus amigos yo tenía los míos. Entonces le propuse que ya que estaba escribiendo publicara, «¿pero cómo voy a publicar?»; «yo te doy una mano» le dije. Nos pusimos a trabajar sobre un poema que él escribió y salió el libro Las alambradas de la luz, que es sobre la construcción de la Catedral. Está bueno el trabajo y lo hicimos en serigrafía porque yo era serigrafista. Pero no solamente la tapa, los textos también eran serigrafías. Quedó muy lindo el trabajo, en colores, diseño alargado. Y bueno, en ese trabajo fue mejorando la relación. (Entrevista a Chaves, 01/03/2019)

A partir de la intervención pública que implicaba la edición del poemario, el diálogo familiar se convirtió en un cruce y una interpelación generacional más amplia, el proyecto editorial construyó una comunidad negativa, la comunidad de quienes no tenían comunidad y portaban la 
memoria extratemporal de un pasado que no había sido vivido jamás en el presente. En este sentido, el título de la colección, creado por Gonzalo Chaves (h) fue muy significativo: Los hijos de la teta del ciclón. A diferencia de lo que en una primera aproximación puede sugerir, el arrasamiento de los hogares, el desamparo, los efectos del terror, también permite pensar en el ciclón como un fenómeno propio de las áreas geográficas tropicales, y relacionarlo con el cimbronazo histórico que significó la Revolución cubana en la generación de madres y padres, el cual se simboliza en esa teta que alimentó los sueños revolucionario que los hijos como herederos conservan todavía en su memoria. ${ }^{8}$

\section{Poéticas de la memoria}

El interés por comprender a su hijo le permitió a Chaves generar vínculos con otros hijo que seguramente también sintieron que podían suspender al menos momentáneamente, en el territorio de la poesía, la inducción social a la culpa y a la vergüenza por ser descendientes de «subversivos». Clasificación social que contribuía ya en democracia a la reproducción de lo que Daniel Feierstein denomina la realización simbólica del genocidio, cuando los responsables y cómplices por acción u omisión, establecen las formas en las que debe narrarse, recordarse y representarse la realización material. Cuando la entrevisté a Andrea Suárez, recordando este período reflexionaba:

Yo era hija del enemigo de la Nación. Entonces qué podía decir (...) había que poner una lupa en el barrio, cómo te miraba el de al lado. Y la victimización también porque pobrecita, pero no sabías si era porque se quedó sin madre o porque pobrecita qué madre le tocó que no pensó (...) me resultaba muy difícil hablar. (Entrevista a Suárez Córica, 29/09/2017)

En el poema «Proceso» de Alas del alma (1992), el yo lírico se apropia del lenguaje y las taxonomías dictatoriales para elaborar y problematizar lo siniestro en el presente de la escritura: «y como designio social mis labios se clausuraron/y en un escondite,/mi propio muro de ladrillos rojos vena,/ sobrevivieron» (28). Varios poemas de la colección dan cuenta de esta imposibilidad de decir. Treinta años después, contemplamos cómo este archivo azaroso y contingente de escrituras poéticas abogaba por otro régimen de legibilidad y decibilidad histórica, que recién encontraría formas más organizadas para su vehiculización y acción política con la conformación de H.I.J.O.S. en 1995. Sin proponérselo, también cuestionaba cierta tendencia de la poesía contemporánea que no problematizaba la historia ni el futuro, mientras que abundaba en las descripciones de un presente denso imbuido por una estética objetivista (Prieto y Helder; Bustos, 200o; Porrúa; Kamenszain).

Varios de los textos reunidos suponían una irrupción de la historia, la cual permitía comprender los efectos sociales del genocidio, las contramarchas y los destiempos en el establecimiento de una causalidad perdida, junto con el restablecimiento de una continuidad en la narración del propio yo, en definitiva, un trabajo de memoria que tal como lo define Elizabeth Jelin, tiende a la reconstrucción de las identidades individuales y colectivas de las sociedades que elaboran períodos caracterizados por la violencia y el terror.

De esta manera, los poemarios escenifican un proceso de construcción identitaria que en los versos de Diego Larcamón señalan la necesidad de restituir en su dignidad las voces poéticas ausentes en la sociedad de la posdictadura, no como consecuencia del olvido por su calidad literaria, sino porque habían sido desaparecidas: «veía calles desoladas por los gritos callados en el 
alquitrán/ como poemas nunca dichos, como esos entreveros que tiene la/ historia para ocultar la verdad hasta desaparecerla» (Larcamón:3). Estos versos también equiparan la destrucción de la generación de los setenta con la destrucción de la poesía misma y abogan por la necesidad de discutir la diferenciación tajante entre poesía y vida que experimenta el campo literario de los noventa (Hernaiz). Larcamón rastrea las vejaciones del lenguaje y lo siniestro de ciertos giros cotidianos para dar cuenta de la imposibilidad de construir un relato tranquilizador en torno al pasado reciente. Una imagen de Variaciones del agua soleada, más que apuntar a un problema individual, hace alusión a una experiencia social: «dosificaron su mente seccionándola en capítulos: cremaron su/lengua con electroshocks sistemáticos» (5).

Estos poemas ponen en evidencia lo que Silvia Schwarböck señala como la sobreabundancia de discursos que en la sociedad de la posdictadura se saben no verdaderos, porque no apelan a la instauración de un nuevo orden más verdadero, guiados por la experiencia de lo irrepresentable, el Pueblo, sino que se reducen al conformismo de lo dado como único, la vida de derecha. En este sentido, retomando a Adorno, plantea que en una sociedad falsa solo el arte es verdadero porque expresa lo que no puede decir-leer-pensar-ver la sociedad. La explicación tranquilizadora que la «teoría de los dos demonios» le proporcionaba a la sociedad civil autoamnistiada de responsabilidades, más allá del consenso brindado no solo a la dictadura sino a la implementación de las Leyes de impunidad ${ }^{10}$ era lo que estos jóvenes querían cuestionar desde la poesía, el pacto social renegativo. El contexto era el de un pasaje en el imaginario social y político de la «teoría de los dos demonios» alfonsinista a la «teoría de la reconciliación nacional» menemista. Esta teoría continuaba a la primera, ya que equiparaba «los terrorismos» para solicitar desde el Estado, la necesidad de reconocimiento mutuo de errores y aciertos para la unidad nacional, promoviendo en el imaginario una idea de reparación de las heridas del pasado a través del mutuo perdón.

En este marco, es interesante señalar la aparición de lo que Schwarzböck denomina los espantos, noción que toma de una escena del film La mujer sin cabeza (2008) de Lucrecia Martel y que vamos a rastrear continuamente en los poemas de estos jóvenes: «lo que la dictadura depara con su victoria económica — los espantos: un plural sin singular — no se hace explícito, como objeto estético, ni bien los represores dejan el gobierno: recién entra en el régimen de la apariencia pura, convirtiéndose en un objeto explícito en la década del noventa» (Schwarzböck:25). Con la implosión del bloque soviético se produjo un giro a lo ficcional y a la no verdad en política a partir de la propagación del neoliberalismo como versión univoca de la historia. Por lo tanto, desde esta perspectiva, el rol del poeta no va a ser tanto el de develar verdades sino más bien el de detenerse y trabajar la apariencia para desautomatizar las percepciones. Los textos de este corpus poético se relacionan con las características que Schwarzböck le asigna a la estética posparanoica, la cual relaciona los espantos, internamente, con la explicitud que los hace aparecer, como poderes clandestinos a plena luz del día, sobreexpuestos. Es necesario señalar que en Schwarzböck encontramos una definición ambivalente de los espantos y aunque vibre una dentro de la otra en el acontecimiento estético, expresan distintos niveles ontológicos: por un lado el espectro, lo desaparecido, y por otro las figuras vivas del presente. Las voces de los espectros se acoplan, se superponen a las de los excluidos por el Estado neoliberal.

La dimensión gnoseológica abierta por los sueños (Córica) o el uso de alucinógenos y drogas (Chaves, Larcamón) permiten acceder a un plano más real, amplía los horizontes de receptividad y legibilidad, alejándose de marcos de percepción habituales, cotidianos, que se tornan peligrosos. 
En un libro posterior de Andrea Suárez Córica, Atravesando la noche. 79 sueños y testimonio del genocidio (1996), la narración de sueños juega con la superposición de espantos y tiempos. En la entrada del 17 de marzo de 1992 escribe: «Estoy leyendo un diario del 8 de abril de 1975. Los titulares dicen "Cierre de fábricas" y "Más despidos"» (14); mientras que en la de febrero de 1994 se produce una superposición entre los obreros despedidos de Entel, los desaparecidos y la ronda de las Madres de Plaza de Mayo: «Mi papá me espera en el Fiat 600 con mis hermanos pero yo me voy caminando. Me encuentro con una compañera de la primaria y le cuento lo que me pasa. Seguimos caminando y llegamos hasta una movilización de telefónicos que caminan alrededor de un carretel de cable. Un señor me hace lugar y nos metemos en la ronda» (28-29).

También hallamos la aparición de los espantos en algunos poemas de Suárez Córica: «para qué buscarlos/ si eso implica morir un poco./ Para qué pensarlos/ si sus imágenes me asustan./ Para qué extrañarlos/ si es en vano./ Para qué mentirme/ si ya no me creo./ Para qué soñarlos/ si me envuelvo en pesadilla» (31). En esa indeterminación del referente se juega lo siniestro de la política desaparecedora. Estos muertos que pesan como una pesadilla habitan todavía en el tiempo presente." Larcamón también vislumbra los espantos en "Dolores», son las "sombras que revolotean por las chimeneas/ dolor ciego, sigiloso, que me licúa las flores» (18), incluso adquieren la fuerza de fenómenos naturales que posibilitan la transmisión de la memoria a los propios hijos-nietos, leemos en «Los gurises»: «LOS NIÑOS SON LOS BARQUITOS DE PAPEL QUE NUESTRAS/VELAS DEBEN ACOMPAÑAR JUNTO CON EL VIENTO DE LOS SAUCES» (15). Otra figuración de los desaparecidos como fuerza que empuja encontramos en Chaves: «Ellos no han dejado nunca de existir, fueron para/ nosotros, locomotora en la belleza, callejuela/ en los relámpagos, pasadiscos en la tristeza/ fueron quizás altos amores/ las sombrillas invendibles/ en los modernos remates del alma» (21). Una memoria que ampara, resguarda y que protege de la intemperie sin sucumbir al consumismo y a la apariencia que todo lo contamina. De alguna forma estos textos dan cuenta del mismo problema que plantea uno de los poetas más representativos de esta generación, Martín Gambarotta, cuando en Punctum (1996), apenas unos años después, sentencia que en ese presente: «todo acto es literario/y eso apesta. Todas las cosas, rogando por sinceridad» (6o). ${ }^{2}$

\section{Políticas del presente}

Las alambradas de la luz de Gonzalo Chaves es un extenso poema dedicado a los constructores de la Catedral de La Plata, el poemario actualiza la tradición brechtiana de «Preguntas de un obrero que lee» (1935): «La historia no sólo ocultó hechos/ no seamos ingenuos/ la misión de la historia fue ocultar al hombre» (Chaves, 1991:12). Por eso trabaja con las memorias de los obreros inmigrantes, sus mujeres, diversiones y penurias, en un juego de continuo descentramiento de la mirada, con un yo lírico que cambia constantemente de perspectivas: por momentos es un obrero que contempla la ciudad de las alturas, por momentos un niño que pasa con su madre por la vereda y observa a los constructores en el cielo. Si bien no se detiene tanto en el período de los sesenta-setenta, hay ciertas imágenes o fugas en la escritura que permiten recuperarlo. Chaves, al igual que Suárez y Larcamón, percibe las elipsis, los silencios y la dislexia de su presente: «es por eso que no nos vemos?/ vivimos solos en este país carneado hasta el silencio magnánimo, hasta la tartamudez melódica?/ nos corresponde algo en el festín de las ciudades?» (21).

La búsqueda de un lugar, la pregunta por el espacio que les queda para desarrollar sus propios proyectos luego del fin de la Historia, inevitablemente lo llevará a la discusión con la generación 
de los padres. Hay una transmisión generacional que se percibe rota, llena de lagunas, misterios y desarraigos. De hecho, de niño el autor atravesó por la experiencia de distintos exilios, sin embargo esta trashumancia es experimentada en su testimonio como una condición de posibilidad para rechazar la ceguera de la rutina y la costumbre.

Una anécdota de Chaves padre sintetiza estos problemas transgeneracionales, su hijo y Larcamón asistían a un taller de escritura con Vicente Zito Lema:

Un día lo encontré a Vicente en La Plata y me dice «tu hijo cómo anda? Siempre escribe?»; «Sí» le digo; «ese chico escribe bien, que no deje de escribir decíle»; y me dice: «sabés por qué no se hizo más el taller no»; «No ¿por?» le digo; «Me hicieron un juicio los poetas y me decían que me iban a matar», «¿pero simbólicamente?» y me dice: «no, qué simbólicamente, me querían matar en serio». Lo acusaron no sé de qué, y es la rebeldía de los hijos con los padres y estaba un poco asustado Vicente. Vicente por ahí con su personalidad era muy absorbente y por ahí sintieron que debían liberarse del tirano. Parece que le armaron una farsa de juicio y lo condenaron. (Entrevista a Chaves, 01/03/2019) ${ }^{13}$

Un adjetivo muy utilizado por Chaves de forma cariñosa en el transcurso de la entrevista fue el de «salvajes» para hacer referencia a la generación de los hijos, específicamente a ciertas prácticas que veía con extrañeza, como las de la anécdota referida o por ejemplo el hábito de leer varios libros al mismo tiempo y que él incorporó como técnica, las lecturas cruzadas. Volviendo a Punctum, Gambarotta que también vivió el exilio por la militancia de su padre, pone en boca de Gamboa, un ex guerrillero, estas extrañezas o diferendos que llaman la atención de Chaves padre: «para Gamboa la organización/ no es la cosa más bella/ la organización es la belleza misma. Por eso no soporta/ ver las cosas del desayuno/ terminado dejadas sin levantar/ de la mesa/ (...) Gamboa, como pocas veces hace, tratando de encontrar un orden perdido/ en la desordenación, un mundo en el submundo revuelto» (72).

Más allá de los contrapuntos generacionales en torno a la organización del tiempo o del espacio, en Las alambradas de la luz Chaves (h) reivindica la épica, las aventuras y viajes en los que se vio inmerso a partir del compromiso político de sus padres. La clandestinidad, la persecución y el exilio no como «trauma» sino como posibilidad de ruptura de los límites que impone la rutina: «la sociedad, el mundo/ han hecho de la infancia una curva/ que de no doblarla estalla el alma/ las ideas/ han hecho de los niños un vapor de sueño/ no llevado nunca al mar por nadie» (10).

Por su parte, Andrea Suárez Córica en el prólogo a Alas del alma (1993) aborda otra arista de los problemas con los que debieron lidiar los hijos en su trayectoria escolar: las malas calificaciones en geografía e historia. Esa descalificación institucional la convertía en guardiana de una memoria prohibida, así al yo lírico no lo sostiene una palabra verdadera: «demasiada certeza/demasiado engaño» (44). La propia historia pesa mucho en la adolescencia pero es algo con lo que debe aprender a convivir: «Hacete amigo de tu historia,/ si querés,/ pero no te ates a ella,/ si no querés» (8).

La primera parte de Alas del alma, Otros tiempos, reúne poemas que Andrea escribió entre los 12 y los 15 años, más intimistas y románticos pero atravesados por una ausencia que paraliza al yo lírico: «Cruel y brutalmente/ te alejaron de tus hijos/y de la/ vida misma./ Hubo nada más/ que muerte./ Tu muerte /y la muerte un poco/ de quienes sabían/ de tus afectos» (29). Según nos cuenta, el cuaderno en el que escribía esos poemas llevaba en la tapa una imagen del logo del mundial 78. Este soporte material en el que la autora conservaba sus producciones iniciales pone 
de manifiesto la vida de derecha en términos de Schwarzböck, la cual se desarrolla ininterrumpidamente y continúa como lo dado. Los espantos emergen en la anécdota, entre la escritura y el cuaderno que la sostiene.

El poema «El borde» anticipa la estética de Suárez en Imágenes rotas: «la mirada infinita/ inmóvil/ indolente/ para vaciar de afecto/ la imagen terrible» (47). Mientras que Alas del alma era un libro de autodescubrimiento, en Imágenes rotas ya hay una afirmación de la propia identidad y una asunción de la propia historia, comienza con el verbo ser: «Soy la corriente cálida/ soy la corriente fría/ soy el amor/ soy la memoria» (5). Imágenes rotas contiene poemas más despojados, más pizarnikeanos. Y marca un punto de indiscernibilidad entre literatura y testimonio: «la fijación/ es la salida/ para apoderarme/ del pasado» (23) o «negaron/ mi pasado/ Me negaron» (27). Una peculiaridad de los libros de Suárez Córica es que son acompañados por sus ilustraciones, hay una tensión recíproca allí entre la visión, la palabra y el trazo que puede o no, transformarse en el rastro de un dibujo y que contribuyen a la materialización de la intimidad.

Finalmente, en el extenso poema «La Argentina que los remil parió» de Diego Larcamón hallamos la invectiva de los vencidos que cuestionan la ignorancia y el silencio de quienes aceptaban la impunidad en la que se vivía. También puede ser analizado como una provocación generacional a la militancia de los setenta, para la cual determinadas consignas como «A vencer o morir por la Argentina» o «Libres o muertos jamás esclavos» desplazaba a hijos e hijas a la proyección de esa Argentina imaginada, desatendiendo algunas cuestiones del presente, del ámbito doméstico y privado.

El poema de Larcamón es muy significativo porque se ubica dentro del universo neobarroso perlonghiano, en un intento por reunir una lengua arrasada a través de la fundición de materiales heterogéneos, historias cortadas, elípticas y fragmentarias. En su desarrollo recrea la construcción de un tiempo mítico, el imaginario mitológico andino es recuperado desde un presente que describe y liga, en una suspensión del tiempo cronológico lineal, las sensaciones y retazos de «memorias ancestrales» con una «cicatriz rabiosa de la muerte» (3)..$^{14}$ La viruela y el sarampión, virus de la colonización española, son equiparados con el consumismo como nueva epidemia, en un contexto de salida de la hiperinflación y de instauración del Plan de convertibilidad de Domingo Cavallo (1992). Varias imágenes dan cuenta de la espectacularización de lo clandestino: «se encontró estrellado contra la piel de la ciudad/ amorotonado de verdades» (5). Por otra parte, la utilización de un tiempo sagrado permite al yo lírico exiliarse en «los zaguanes de la creación» (5). La desubjetivación que propicia el arte y la droga le permiten comprender la Historia, falseada en las reproducciones de identidades de mercado. El acto de la escritura posibilita que despierte de su sueño invadido por «un río de conocimientos». Sobre el final se transforma en un Pueblo que conserva la esperanza y espera sin tiempo. En poemas como «No te duermas en el sueño» la proliferación de la apariencia encuentra una vehiculización en la metáfora expandida del sueño como placebo en el contexto neoliberal «Es posible que la desmemoria intente mojarte./ También es predecible que tu brazo más seguro se duerma/ por un mal apoyo y con alas prestadas./ Que no nos duerman en el sueño» (14).

\section{La comunidad inconfesable}

Ediciones Los hijos de la teta del ciclón se configuró como un archivo contingente que reunió a jóvenes poetas hijos de la militancia perseguida en los setenta. A través de los poemarios publicados 
es posible abordar un estado de la memoria acerca de los setenta marcado por un contexto de impunidad para los perpetradores y de repliegue en el compromiso civil para el reclamo por memoria, verdad y justicia del movimiento de derechos humanos. Estos jóvenes encontraron en la escritura un ámbito para elaborar lo reprimido por los discursos hegemónicos sobre los setenta, atravesados por las política de reconciliación nacional promovidas por el gobierno de Carlos Saúl Menem. Estas discursividades no estaban influenciadas todavía por la experiencia de participación o no en H.I.J.O.S., que se conformaría recién dos años después, en 1995.

Por otra parte, constatamos que la elaboración del testimonio a partir de la apropiación de distintas tradiciones poéticas, Brecht en Chaves, el romanticismo y las lecturas de Pizarnik en Suárez o el neobarroso en Larcamón, como diría Barthes deporta a los sujetos y subsume la experiencia a la lógica de la escritura. La experiencia interior no podía tener lugar si se limitaba a una sola individualidad, la cual se hubiera bastado para cargar con el acontecimiento y los efectos del genocidio, como señala Blanchot «ella se cumple, perseverando en la incompletud, cuando se comparte y en el compartimento, expone sus límites, se expone en los límites que se propone transgredir» (42). Aquí radica la acción política de la literatura, en la negación del ser aislado y la apertura a la otredad desconocida: «la experiencia sólo puede ser tal si sigue siendo comunicable porque, en su esencia, es apertura al afuera y apertura al prójimo, movimiento que provoca una relación de violenta disimetría entre el otro y yo: la desgarradura y la comunicación» (48). Con este breve sondeo realizado sobre las poéticas de los autores que publicaron en Los hijos de la teta del ciclón, intentamos aproximar al lector al fenómeno de cómo trabaja el desgarramiento de la apropiación de un lenguaje vejado, negador de la otredad, al interior del acontecimiento poético.

Estas publicaciones azarosas, lejanas (transcurrieron casi treinta años de su edición), perdidas (la única presentación pública la realizó Andrea Suárez Córica en El bar de calle 47 entre 7 y 8 , mientras que Chaves $-\mathrm{h}-\mathrm{y}$ Larcamón regalaban o vendían los poemarios en trenes y plazas), se presentan como un ejercicio temprano de construcción de memorias desde la poesía por parte de la generación de hijos e hijas que va a resignificarse posteriormente como un claro antecedente de lo que fue el proyecto editorial de la colección Los Detectives Salvajes (2007-2015) de Libros de la Talita Dorada. ${ }^{15}$ Obviamente ninguno de los hijos e hijas poetas que formaron parte de Los detectives salvajes conocía de la existencia de los poemarios de Los hijos de la teta del ciclón, prácticamente hay una diferencia de 10 años entre sus nacimientos, ${ }^{16} \mathrm{y}$ sin embargo a sus textos los liga un estilo, una concepción acerca de lo poético, acerca de la necesidad de repensar la historia desde la poesía, que los hermana en una constelación de imágenes, metáforas y búsquedas estéticas compartidas. Finalmente, la recurrencia en Chaves padre de definir a la generación de su hijo como salvaje, modificó nuestra propia perspectiva sobre la colección Los Detectives Salvajes (Tavernini), ahora ya no podemos verla solo como la autodefinición de una formación cultural (Williams) influenciada por las lecturas de Roberto Bolaño, sino también como una visión especular y la reapropiación de una clasificación que reside en la óptica del sobreviviente.

Me gustaría concluir con el poema «Estación Shell Autopista La Plata Buenos Aires» (2019) del último libro de Julián Axat, porque intuyo que allí se cifra la trascendencia de los encuentros fortuitos, de la profundidad de las frases que se hacen eco y hieren la hegemonía temporal, con la promesa siempre a futuro de más literatura. Promesa que signa a esta comunidad de escritores y lectores a la que el mismo poeta se refirió como inconfesable: 
Cargo solo 500 pesos de nafta y entro al café de la estación pido y me siento

bebo de a sorbos cuando veo entrar a Gonzalo Leónidas Chaves

cabizbajo como siempre «el Negro» me saluda y pide lo suyo en la barra

lo invito a sentarse a mi lado

\author{
Hablamos pocos minutos \\ lo suficiente para entrarle a la derrota \\ tema que nadie quiere tocar por estos tiempos \\ pero al que acaba de dedicarle un libro \\ Me mira sin tocar su café humeante \\ sonríe ladino \\ cuando le pregunto por el futuro \\ cita a Walter Benjamin \\ «la Historia voraz un fárrago de posibilidades» \\ «el futuro... hay que inventarlo»
}

Tiene rostro de profeta

cuando sus ojos se hunden entre lágrimas

En ese momento no sé si me está mirando a mí

o al recuerdo de mi viejo cuando tenía mi edad

Poco a poco me doy cuenta

que la palabra invención lo llena de esperanza

y prosigue con el otro «W» ahora Walsh

«...en estos contextos de repliegue

el refugio son las bases

tiempo de seguir y esperar...»

Dice que me hará llegar su libro sobre la derrota

Lo abrazo y le traigo desde el auto unos poemas de regalo

Como todos los días

sigo rumbo a Buenos Aires (35)

\title{
Notas
}

1 En el siguiente link se puede consultar el poema completo: https://elnieuweaca.com/2019/04/11/ni-perla-ni-barro-ni-plata/

2 Algunas experiencias están comenzando a investigarse, por ejemplo en " $E l$ tren de las 4 y 30 ”: lejana, temprana memoria»
(2018) Emiliano Bustos rescata del olvido la importancia del Movimiento Solidario de Salud Mental para la contención de grupos de hijos e hijas de desaparecidos, el cual articulaba sus actividades con otras instituciones de El Salvador, Honduras y 
Chile. Testimonio de estos encuentros son el dispositivo poético-teatral realizado por hijos e hijas El tren de las 4 y 30 (1993), que se presentó en varias ocasiones a lo largo de 1993 y 1994, como así también la antología de textos titulada El lenguaje de un gesto. Poemas, cuentos de jóvenes afectados por el terrorismo de estado en la Argentina (1993).

3 Poeta, artista plástico y docente, hijo de dos históricos militantes del peronismo platense, el escritor y artista plástico Gonzalo Leónidas Chaves y la abogada Amalia Ramella. En 1989 publicó un poemario titulado Significado cero, también diseñado por su padre.

4 Poetayartista plástica.Además publicóAtravesandola noche. 79 sueños y testimonio del genocidio (1996). Es hija de Luisa Marta Córica, poeta, actriz y estudiante de Filosofía en la Universidad Nacional de La Plata, que trabajaba en la Legislatura provincial y era delegada del Sindicato de Empleados para Reunión del Hipódromo. Córica militaba en la Juventud Trabajadora Peronista (JTP) y en la Juventud Universitaria Peronista (JUP). Fue secuestrada y asesinada por un grupo de la Concentración Nacional Universitaria (CNU) platense el 7 de abril de 1975.

5 Único poemario publicado por el autor, hijo de Jorge Larcamón, talabartero, militante del Movimiento de Liberación Nacional (MLN) y de Elba Esther Barbieri, docente y militante del Partido Comunista Marxista Leninista (PCML) desaparecida el 15 de agosto de 1977 en la ciudad de La Plata.

$6 \mathrm{Si}$ bien no pudimos todavía relevar el catálogo completo, entre los títulos que encontramos se destacan en poesía Esta única esperanza contra todo (1973) y Es temprano (1974) de Osvaldo Ballina, Toda la patria cierta (1973) de José Abdelnur y Cartas íntimas para todos (1974) de Néstor Mux. Además, Rubén Pesci publicó Del Ambiente Individual al Ambiente Colectivo (1973) en una colección sobre arquitectura.

7 Con el retorno de la democracia debió exiliarse nuevamente en 1985 por la aplicación del decreto $157 / 83$ del presidente Raúl Alfonsín que ordenaba el enjuiciamiento de las cúpulas de las organizaciones guerrilleras.

8 Chaves (h) nos contó el porqué de la elección, si bien la lectura del autor es distinta, la consideramos complementaria de la que proponemos: «El ciclón era ese momento epocal, los setenta, lo que viví yo como niño se podría traducir en una imagen así. No era algo "normal", pero también tenía su alimento, esa es la teta. No es que estás descobijado. Por qué, porque siempre desde una normalidad - te digo porque me ha pasado algunas veces cuando intento contar algunas cosas y le debe pasar a otras personas-, siempre desde una normalidad se ve algo terrible, pero ese es un problema que tiene la normalidad. Y es un problema que tiene que ver con que la normalidad se piense a sí misma como que está muy bien. Por eso piensa que todo lo diferente puede ser terrible. Si vos le decís a un tipo: "yo en mi infancia estuve clandestino, me cambié de apellido, cambié de país, fui a 8 escuelas, 45 casas"; te dicen: "qué terrible, tremendo". Y bueno, no sé si es tan así porque eso es visto desde la normalidad. Los prejuicios parten desde ahí. Entonces ese ciclón, ese aparente ciclón, esa cosa de turbulencia en realidad amamantaba también» (Entrevista a Gonzalo Chaves —h—, 09/07/2019).

9 Su hijo invitó al proyecto a su amigo y compañero de taller Diego Larcamón, mientras que a Andrea Suárez Córica sus compañeros del Taller de Teatro de la UNLP le recomendaron contactar a Chaves para que publicara sus poemarios inéditos.

10 La Ley 23.492 de Punto Final, fue promulgada el 24 de diciembre de 1986 por el entonces presidente Raúl Alfonsín, y estableció la paralización de los procesos judiciales contra los imputados de ser autores penalmente responsables de haber cometido el delito de desaparición forzada de personas durante la dictadura. Meses después fue complementada con la Ley 23.521 de Obediencia Debida, también dictada por Alfonsín el 4 de junio de 1987, y estableció una presunción iuris et de iure (es decir, que no admitía prueba jurídica alguna en contrario) respecto de que los delitos cometidos por los miembros de las Fuerzas Armadas no eran punibles, por haber actuado en virtud del denominado concepto militar de «obediencia debida» que rige a los subordinados.

11 En la entrada del 3 de febrero de 1996 de Atravesando la noche, hay una aparecida que no asusta, y sobre la que no se detiene la protagonista, como si supiera que la presencia de su madre siempre la acompañará: «estoy andando en moto. Mis hermanos Mariano y Leandro van atrás. Vamos por la calle 122, cerca del Bosque. En cada esquina hay una situación de peligro, frena un camión, pasa alguien. Paso por la avenida 520. Hay una camioneta estacionada. Cuando la paso, miro hacia tras. Hay una mujer igual a mi mamá, rubia, con el pelo atado, con un extraño traje de novicia. Es ella. No freno pero sé que es ella» (36). Por otra parte, también da cuenta de la imposibilidad de establecer un contacto directo con ese espectro, escribe en la entrada del 14 de noviembre de 1991: «Mamá vive en el departamento de la 
calle 47. Voy a visitarla. Tengo miedo de que me abrace y que al hacerlo se convierta en fantasma» (14).

12 No es casual que Martín Gambarotta haya atravesado también la experiencia del exilio, vivió con sus padres en Inglaterra entre 1977 y 1983. En una entrevista con Osvaldo Aguirre reflexiona sobre los efectos, en la literatura contemporánea, de esa vivencia generacional: «Tal vez sea interesante pensar cuál fue, en términos de la lengua, el efecto de cierta cantidad de ciudadanos que se fueron, cierta cantidad de ciudadanos que volvieron, sean de donde sean, y también el efecto que eso pudo llegar a tener en la literatura» (Aguirre:153).

13 Gonzalo Chaves (h) niega la anécdota del juicio, aunque coincide en que hubo problemas que atribuye a cuestiones relacionadas con la metodología de trabajo propia de los talleres literarios de la época: «no fue tan así (...) No hubo ningún juicio, lo que pasa es que naturalmente se dio algo... que por ahí él acostumbrado a otros talleres, que me parece bárbaro, porque los talleres muchas veces funcionan así, de una manera medio paternalista. En verdad los viejos talleres funcionaban así. Un escritor reconocido y la gente iba. Y Vicente acá se encontró con un grupo que tenía un cierto peso propio y que produjo algunos pequeños hechos, y naturalmente se dio cierto cuestionamiento, nada excesivo, no un juicio. Yo le reconozco a Vicente que hizo algo muy interesante, pero es normal que pibes de 24 años (...) por ahí el venía con un rol, sin ser una persona injusta eh, era muy bondadoso» (Entrevista a Chaves (h), 09/07/2019). Además de Larcamón y Chaves al taller de Zito Lema asistían Gabriela Pesclevi, Miguel Sendón y Daniel Urrizmendi.

14 Las mismas reminiscencias de la mitología andina hallamos en Significado cero (1989) de Gonzalo Chaves: «en el Titicaca iridiscente, por caminos de piedras y de polvo se encuentra
Tiwanacu. Arquitectura Solar, fuera de toda escala humana y fuera de toda pregunta con respuesta, allí murió para mí la palabra grande como un intento por decir algo. Ante sus ruinas solo atiné a quedarme mudo ante un silencio que puede más que nuestro idioma» (5), y en Atravesando la noche (1996) de Andrea Suárez: «Estoy con mi vecino en el lago Titicaca, en Bolivia. En el lago se forma una gran tormenta. Las olas se llevan su Falcon verde. Lo veo flotar bruscamente en el agua pero no podemos hacer nada. Veo la masa de agua hirviendo» (13).

15 El proyecto editorial de Los Detectives Salvajes puede entenderse como una singular acción de memoria emprendida por dos hijos de militantes setentistas, Juan Aiub y Julián Axat. Reunió los escritos de poetas desaparecidos o asesinados durante la última dictadura cívico-militar o en un momento previo (Carlos Aiub, Jorge Money, Rosa María Pargas, Joaquín Areta, Luis Elenzvaig, José Carlos Coronel), cuyos cuadernos y libros circularon durante largo tiempo como archivos familiares o de compañeros de militancia. El catálogo está conformado también por poemarios o poemas reunidos en antología de hijos de militantes desaparecidos, asesinados o exiliados (Juan Aiub, Emiliano Bustos, Julián Axat, Nicolás Prividera, María Ester Alonso, Pablo Ohde, Alejandra Szir, Jorge Ignacio Areta, Verónica Sánchez Viamonte, Ramón Inama).

16 Habría que hacer la salvedad de que Andrea Suárez Córica sí participó del proyecto de Los detectives salvajes solo que no como autora, sino trabajando en la edición del poemario La niña que sueña con nieves (2015), que su madre Luisa Marta Córica había dejado mecanografiado antes de que una patota de la Concentración Nacional Universitaria la asesinara en 1975. Por otra parte, el libro de sueños Atravesando la noche (1996) fue ampliamente leído por el grupo.

\section{Referencias bibliográficas}

Aguirre, O. (2014). La poesía en estado de pregunta. Buenos Aires: Gog \& Magog.

Araldi Oesterheld, F. (2014). El sexo de las piedras. Buenos Aires: Mansalva.

Axat, J. (2019a). Cuando las gasolineras sean ruinas románticas. La Plata: Prueba de Galera.

(2019b). «El futuro (a modo de respuesta a Alejandra Szir)», 17 de agosto, inédito.

Blanchot, M. (2002). La comunidad inconfesable. Madrid: Editora Nacional.

Bustos, E. (2000). La generación poética de los 90. Hablar de poesía, (3), 98-103.

(2018). El tren de las 4 y 30 : lejana, temprana memoria. Aesthethika. Revista Internacional sobre subjetividad, política y arte, 14, 43-56. 
Chaves, G. (h) (1989). Significado cero. La Plata: Los hijos de la teta del ciclón.

(1991). Las alambradas de la luz. La Plata: Los hijos de la teta del ciclón.

Feierstein, D. (2012). Memorias y representaciones. Sobre la elaboración social del genocidio. Buenos Aires: Fondo de Cultura Económica.

Gambarotta, M. (2011). Punctum. Buenos Aires: Vox-Mansalva.

Hernaiz, S. (2012). Rodolfo Walsh no escribió Operación masacre y otros ensayos. Buenos Aires/Bahía Blanca: 17 grises.

Jelin, E. (2002). Los trabajos de la memoria. Madrid: Siglo XXI.

Kamenszain, T. (2007). La boca del testimonio. Buenos Aires: Norma.

Larcamón, D. (1993). Variaciones el agua soleada. La Plata: Los hijos de la teta del ciclón.

Porrúa, A. (2003). Lo nuevo en la Argentina: poesía de los 9o. Foro Hispánico: revista hispánica de Flandes y Holanda, (24), 85-96.

Prieto, M.y García Helder, D. (1998). Boceto $n^{\circ} 2$ para un... de la poesía argentina actual. Punto de vista, (60), 13-18.

Schwarzböck, S. (2016). Los espantos. Estética y postdictadura. Buenos Aires: Cuarenta Ríos.

Suárez Córica, A. (1992). Alas del alma. La Plata: Los hijos de la teta del ciclón. (1993). Imágenes rotas. La Plata: Los hijos de la teta del ciclón.

(1996). Atravesando la noche. 79 sueños y testimonio del genocidio. La Plata: De la Campana.

Szir, A. (2019a). Ni perla ni barro ni plata. El Niewe acá. Un fanzine de literatura menor. Holanda. https:// elnieuweaca.com/2019/o4/11/ni-perla-ni-barro-ni-plata/

(2019b). «El presente», 16 de agosto, inédito.

Tavernini, E. (2019). Poesía, política y memoria en la Argentina reciente. La colección Los Detectives Salvajes (2007-2015) (Tesis de Maestría en Historia y Memoria). Universidad Nacional de La Plata. http://www. memoria.fahce.unlp.edu.ar/tesis/te.169o/te.169o.pdf

Williams, R. (1980). Marxismo y literatura. Barcelona: Península.

\section{Entrevistas}

Entrevista realizada a Andrea Suárez Córica el 29/09/2017 en su domicilio, La Plata.

Entrevista realizada a Gonzalo Leónidas Chaves el 01/03/2019 en «El pasaje bar», La Plata.

Entrevista realizada a Gonzalo Chaves el 09/07/2019 en «El pasaje bar», La Plata. 